\title{
Lagochilascaris minor LEIPER, 1909 (NEMATODA: ASCARIDIDAE) IN MEXICO: THREE CLINICAL CASES FROM THE PENINSULA OF YUCATAN
}

\author{
Mario BARRERA-PÉREZ(1), Pablo MANRIQUE-SAIDE(2), Enrique REYES-NOVELO(1), Javier ESCOBEDO-ORTEGÓN(1), \\ Manuel SÁNCHEZ-MORENO(3) \& Cuauhtémoc SÁNCHEZ(4)
}

\begin{abstract}
SUMMARY
Human lagochilascariasis (HL) is a parasite produced by Lagochilascaris minor Leiper 1909 that also can be found in cats and dogs. $\mathrm{HL}$ is considered an emerging zoonosis in the Americas, spreading from Mexico to Argentina, and the Caribbean Islands. The present paper describes three HL cases from the Peninsula of Yucatan, Mexico, recorded in the last decade. It describes the characteristics of the lesions and discusses the route of transmission in humans and particularly in the observed patients.
\end{abstract}

KEYWORDS: Lagochilascaris minor; Parasite; Helminth; Yucatan - Mexico.

\section{INTRODUCTION}

Lagochilascariasis is a parasitic disease caused by Lagochilascaris helminths in different mammal reservoirs. Human lagochilascariasis (HL) is a zoonosis caused by Lagochilascaris minor Leiper 1909 which also can be found in cats and $\operatorname{dog} \mathrm{s}^{1}$. HL is considered an emerging zoonosis in the Americas, spreading from Mexico to Argentina and the Caribbean Islands ${ }^{8}$. $\mathrm{HL}$ is common in people living in slums and especially people from rural areas ${ }^{5}$.

The life cycle of L. minor is still unclear; eggs, larvae, and adult worms have all been found on lesions in both animals and humans ${ }^{8}$. A heteroxene cycle has been proposed after various studies with experimental models with rodents as intermediary hosts, since the parasite's development stops at the third stage larvae (L3) and turns into a cyst form. In felines (definitive hosts), L. minor reaches the adult stage with the presence of all life stages in the associated lesions $\mathbf{s}^{2,7,11}$. Under these conditions, L. minor infections are acquired by the ingestion of encysted L3 found in the intermediary hosts (rodents), from raw or uncooked meat ${ }^{7}$. It is eventually followed by autoinfection and the development of chronic disease $e^{4,14}$.

Infestation in animals and humans with $L$. minor causes a range of clinical manifestations along the course of infection, from mild to severe as the parasite invades the pulmonary tissue and the central nervous system, with fatal results ${ }^{8,9,10}$. L. minor lesions in animals and humans characteristically result in tumors and fistulas with cutaneous and subcutaneous abscesses localized in the cervical region and surrounding tissues. However parasite lesions of the mastoids, jaw, tonsils, maxillary and paranasal sinuses, middle ear, oropharynx, pharynx, dental alveoli and central nervous system have been observed ${ }^{8}$.

Two cases of HL in Mexico have been published previously, one in Chalco, Mexico and one in Villa Azueta, Veracruz ${ }^{10,13}$. Here we report and describe three HL cases from the Peninsula of Yucatan (PY), seen in the states of Campeche and Yucatan, recorded during the last decade.

\section{DESCRIPTION OF CLINICAL CASES}

Case 1. Patient was a 50 year old female, housewife, from the state of Campeche, Mexico. On February $12^{\text {th }}$ of 2002 the patient sought medical care for a draining, fistulous lesion in her left sub maxillary region, of ten years duration. The lesion started with an increase of size of the left salivary gland and a purulent discharge with white filaments. At time of admission treatment with antibiotics resulted in a discrete improvement, but no definite healing. During physical examination, the presence of small parasites at the bottom of the productive fistulous lesion was observed; the parasites were identified as L. minor (Fig. 1A). Patient also had painful cervical lymphatic nodes during the examination. The treatment was changed to pyrantel pamoate ( $750 \mathrm{mg}$ for five days). Improvement was seen after one week with complete resolution at the end of the third week after treatment.

Case 2. Patient was an 18 year old male, Mennonite farmer (German descendance), from the state of Campeche, Mexico. On April 24 ${ }^{\text {th }}$ of 2007 the patient sought medical care presenting with fever, anorexia, significant weight loss, and productive cough. The illness started three years prior to consultation. On examination tiny parasites were observed in the patient's

(1) Laboratorio de Zoonosis y otras Enfermedades Transmitidas por Vector, Centro de Investigaciones Regionales "Dr. Hideyo Noguchi” Universidad Autónoma de Yucatán, Mexico.

(2) Departamento de Zoología, Campus de Ciencias Biológicas y Agropecuarias, Universidad Autónoma de Yucatán, Mexico.

(3) Laboratorio de Parasitología Molecular, Facultad de Ciencias, Universidad de Granada, Spain.

(4) Servicios de Salud del Estado de Yucatán, Mexico.

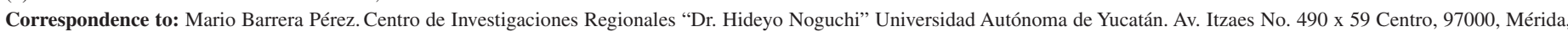
Yucatán, México. Tel +52 99992457 55; Fax: +52 99992361 20. E-mail: bperez@uady.mx 


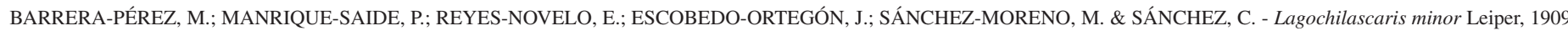
(Nematoda: Ascarididae) in Mexico: three clinical cases from the Peninsula of Yucatan. Rev. Inst. Med. Trop. Sao Paulo, 54(6): 315-7, 2012.

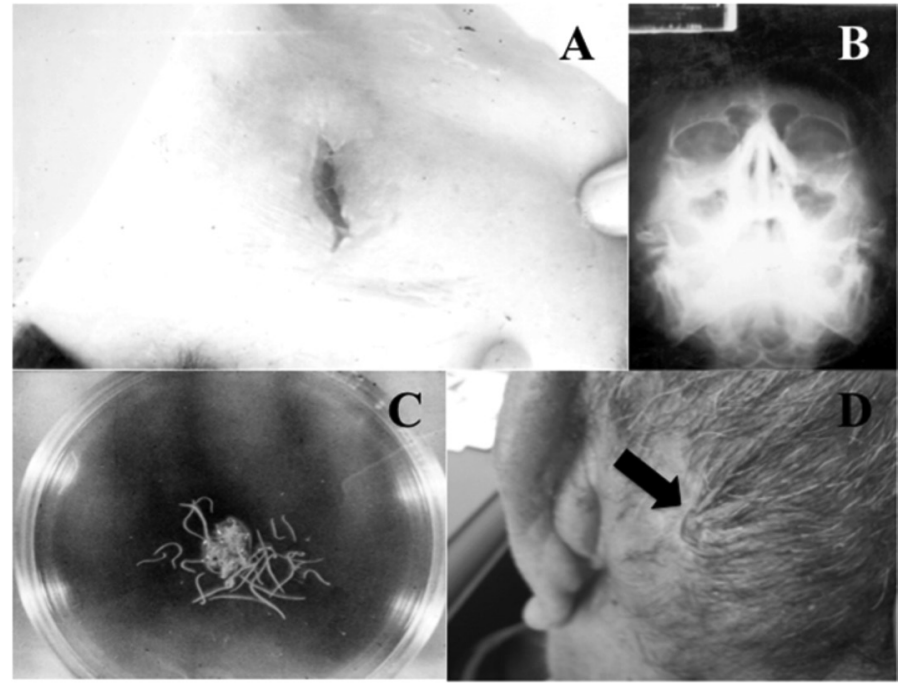

Fig. 1 - Different lesions caused by Lagochilascaris minor Leiper, 1909 in patients from the Yucatan Peninsula, Mexico. Fistulous lesion at the left submaxillary area (A). X-Ray showing sinusitis (B). L. minor parasites gathered from patient sinuses (C). Draining fistulous lesion at the left mastoid area (D).

nasal secretions. He was previously diagnosed with sinusitis and received antibiotic treatment and a single dose of albendazol $(400 \mathrm{mg})$, with no improvement. During the physical exam the patient was significantly thinner with a temperature of $37.8^{\circ} \mathrm{C}$ and moderate size cervical lymph nodes. An X-Ray examination showed sinusitis (Fig. 1B) and the lab exam identified the parasite L. minor (Fig. 1C). Patient was treated with albendazol (400 mg) for 30 days; improvement was seen after the first week with complete resolution after one month.

Case 3. Patient was a 67 year old male, alcoholic, and garbage scavenger from the state of Yucatan. On August $11^{\text {th }}$ of 2011 the patient sought medical care for a draining, fistulous lesion at the left mastoid region; purulent discharge contained tiny parasites. The lesion started two years prior to consultation with a small draining lymph node when it was drained several times and treated with antibiotics. After the first year the purulent discharge presented with tiny parasites. He was then diagnosed with intense parasitic infection and hospitalized for one month. Patient could not recall the treatment that he had received while admitted. At the end of the second year the patient continued with the productive purulent lesion (Fig. 1D) with parasites that were identified as L. minor. He then received treatment with albendazol (400 $\mathrm{mg}$ a day for 30 days), after one week the lesion had resolved but the patient did not return to the 30 day follow up.

\section{DISCUSSION}

The increase in diagnosis and reports of HL cases in recent years may suggest increased transmission and emergence of $L$. minor ${ }^{5}$. In the last decade there have been two recorded cases of $L$. minor infections in Mexico, as well as the three cases presented in this report ${ }^{10,13}$. The characteristics of the HL lesions observed in the described patients are similar to those documented in other geographic areas, except for the submaxillary lesion discussed in case 1 , which is very uncommon for L. minor infections ${ }^{8}$.
The route of infection for the presented cases is uncertain. Ingestion of raw or undercooked rodent meat is normally how humans become infected but all patients denied consuming rodent. An alternative mode of infection is from the ingestion of eliminated eggs from the definitive hosts ${ }^{1}$. Two of the case patients worked in outdoor and farming environments and one was a garbage scavenger, which allowed for exposure to rats or other wild animals. The housewife in case 1 stated that she performed house care in two different cities in which she might have been exposed to rodents.

In the Yucatán, the illegal hunting and consumption of wild animals is a common practice, allowing for the ingestion of encysted larvae from wild animals as a route of infection ${ }^{3}$. Recognized bush meat species in the Peninsula include: white-tailed deer (Odocoileus virginianus), red brocket deer (Mazama americana), collared peccary (Tayassu tajacu), paca (Agouti paca), Central American agouti (Dasyprocta punctata), and eastern cottontail (Sylvilagus floridanus). Ungulates (i.e. deer) and rodents (i.e. paca, aguti) are mammals associated with $L$. minor infection of cats and humans in Brazil ${ }^{6,12}$.

Although the details of the heterogenic lifecycle are uncertain, current research indicates that two species are required for $L$. minor lifecycle completion ${ }^{7}$. Humans are considered incidental hosts with a similar cycle progression of infection and lesions as documented in domestic cats, including the presence of different life stages of the parasite in the same host. As proposed by VARGAS-OCAMPO et al.${ }^{13}$ humans may represent an alternative definitive host when considering the amount of worms, the number of eggs produced, and the length of parasitic infestation observed in infected patients.

Lagochilascaris minor is not a common human parasite and there is no epidemiological study on the prevalence of this parasite in Mexico. The true prevalence of HL may not be known due to incorrect diagnosis and under-reporting of infection. All of the patients in this study reported having received multiple ineffective treatments as their lesions were treated as bacterial infections. Adequate diagnosis and prompt treatment of suspected $\mathrm{HL}$ is required. Further research is needed about the life cycle and all possible modes of transmission throughout the Yucatan to understand the epidemiology and dynamics of this emerging zoonotic disease.

\section{RESUMEN}

\section{Lagochilascaris minor Leiper, 1909 (Nematoda: Ascarididae) en México: tres casos clínicos de la Península de Yucatán}

La Lagochilascariasis humana (HL) es producida por Lagochilascaris minor Leiper, 1909; el cual es un parásito que puede ser encontrado también en gatos y perros. HL es considerada una zoonosis emergente en América distribuida desde México hasta Argentina y las islas del Caribe. El presente artículo describe tres casos de HL en la Península de Yucatán, México registrados en la última década. Se describen las características de las lesiones y se discute la ruta de transmisión en humanos y particularmente en los pacientes observados.

\section{ACKNOWLEDGMENTS}

The authors thank Jessica Malachowski for the English and critical review of the manuscript. 


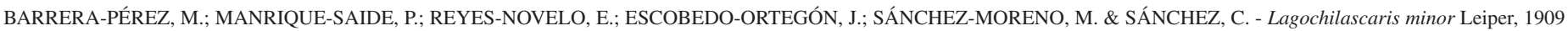
(Nematoda: Ascarididae) in Mexico: three clinical cases from the Peninsula of Yucatan. Rev. Inst. Med. Trop. Sao Paulo, 54(6): 315-7, 2012.

\section{REFERENCES}

1. Acha PN, Szyfres B. Zoonosis y enfermedades transmisibles comunes al hombre y a los animales. v. III: Parasitosis. Washington: Organización Panamericana de la Salud; 2003. (Publ. Cient. Tec. № 580).

2. Barbosa CAL, Barbosa AP, Campos DMB. Gato doméstico (Felis catus domesticus) como possível reservatório de Lagochilascaris minor Leiper, 1909. Rev Patol Trop. 2005;34:205-211.

3. Campos DMB, Freire-Filha LG, Vieira VM, Paçô JM, Maia MA. Experimental life cycle of Lagochilascaris minor Leiper, 1909. Rev Inst Med Trop Sao Paulo. 1992;34:277-87.

4. Fraiha-Neto H, Leão RNQ, Costa FSA. Lagochilascariase humana e dos animais domésticos. Zoonoses Rev Int. 1989;1:25-33.

5. Guimaraes VC, Barbosa AP, Camargo LA, Siqueira PH, Filho JCS, Castro VLS, et al. Otomastoidite por Lagochilascaris minor em criança: relato de caso. Arq Int Otorrinolaringol. 2010;14:373-6.

6. Paçô JM, Campos DMB, Maia MA, Freire-Filha LG, Vieira MA. Lagochilascaris minor infecção experimental em Dasyprocta agouti. Rev Inst Med Trop Sao Paulo. 1991;33(Suppl 8):S40.

7. Paçô JM, Campos DMB, Oliveira JA. Wild rodents as experimental intermediate hosts of Lagochilascaris minor Leiper, 1909. Mem Inst Oswaldo Cruz. 1999;94:441-9.
8. Palheta-Neto FX, de Leão RNQ, Neto HF, Tomita S, de Lima MAM, Pezzin-Palheta AC. Contribução ao estudo da Lagochilascariase humana. Rev Bras Otorrinolaringol. 2002;68:101-5.

9. Rosenberg S, Lopes MB, Masuda Z, Campos R, Vieira BMC. Fatal encephalopathy due to Lagochilascaris minor infection. Am J Trop Med Hyg. 1986;35:575-8.

10. Román-López E, Rosas-Carrasco O, Sánchez-Zúñiga MJ, Alexanderson-Rosas EG, Soto-Abraham V, Santiago-Santiago R, et al. Lagochilascariosis en un paciente con diabetes tipo 2. Evolución aguda y mortal. Reporte del primer caso en la literatura. Med Interna Mex. 2003;19:255-8.

11. Semerene AR, Lima R de S Jr, Oliveira JA, Magalhães AV, Stefani MN, Barbosa AP, et al. Experimental lagochilascariosis: histopathological study of inflammatory response to larval migration in the murine model. Mem Inst Oswaldo Cruz. 2004;99:393-8.

12. Sudré AP, Uchôa F, Brener B. Lagochilascaris in a housecat and the potential risk for human disease. Brazil J Infect Dis. 2012;16:111-2

13. Vargas-Ocampo F, Alvarado-Alemán FJ. Infestation from Lagochilascaris minor in Mexico. Int J Dermatol. 1997:36:56-8.

14. Volcan GS, Medrano CE, Payares G. Experimental heteroxenous cycle of Lagochilascaris minor Leiper, 1909 (Nematoda: Ascarididae), in white mice and cats. Mem Inst Oswaldo Cruz. 1992;87:525-32.

Received: 10 April 2012

Accepted: 6 July 2012 